\title{
Pengaruh Kualitas Pelayanan Terhadap Kepuasan Konsumen Pada Super Daily Mart Betung
}

\author{
Benny Usman \\ Manajemen, Fakultas Ekonomi Universitas PGRI Palembang \\ email: benny usman@univpgri-palembang.ac.id
}

\begin{abstract}
ABSTRAK
Permasalahan yang dibahas dalam penelitian ini adalah apakah ada pengaruh kualitas pelayanan terhadap kepuasan konsumen pada Super Daily Mart Betung. Populasi dalam penelitian ini adalah konsumen yang telah membeli dan menggunakan produk pada Super Daily Mart Betung yang berjumlah 2.484 konsumen. Sampel dalam penelitian ini berjumlah 96 konsumen Super Daily Mart Betung. Metode yang digunakan dalam penelitian ini dalah deskriptif kuantitatif. Teknik pengumpulan data yang digunakan yaitu kuesioner dan dokumentasi. Berdasarkan hasil pengujian dengan menggunakan persamaan regresi linier sederhana diketahui persamaan regresinya adalah $Y=16,814$ $+0,342 \mathrm{X}$ dan terdapat pengaruh signifikan antara kualitas pelayanan terhadap kepuasan konsumen yang ditunjukan dengan thitung $=3,938$ lebih besar dari tabel $=1,661$.
\end{abstract}

Kata Kunci: Kualitas Pelayanan dan Kepuasan Konsumen.

\section{A. Latar Belakang}

Seiring dengan berkembangnya dunia usaha, banyak perubahan yang terjadi dalam aktivitas usaha untuk meraih sukses bagi setiap perusahaan. Demikian juga dengan halnya dengan persaingan di dunia usaha akan semakin meningkat. Dengan semakin banyaknya produsen yang terlibat dalam pemenuhan kebutuhan dan keinginan konsumen menyebabkan setiap perusahaan harus menempatkan orientasi pada kepuasan konsumen sebagai tujuan utama. Syarat yang harus dipenuhi oleh suatu perusahaan agar dapat berhasil dalam persaingan adalah berusaha mencapai tujuan untuk menciptakan dan mempertahankan pelanggan. Perusahaan harus memiliki kemampuan untuk mengenal konsumennya serta mengerti apa yang dibutuhkan dan diinginkan oleh konsumen agar mereka dapat memperoleh kepuasan. Salah satu jalan yang ditempuh oleh perusahaan adalah dengan cara meningkatkan kualitas pelayanan. Apabila konsumen sudah merasa puas, diharapkan konsumen kembali untuk membeli lagi dan bertahan menjadi pelanggan tetap dari suatu perusahaan.

Perubahan perilaku pembeli dan gaya hidup masyarakat secara umum merupakan hal penting yang harus diperhatikan oleh para pengusaha agar dapat menjamin kelangsungan hidup usahanya. Misalnya pada masyarakat di kota-kota besar, dengan semakin tingginya tingkat kebutuhan, saat ini semakin banyak masyarakat yang lebih memilih dan lebih menyukai dan melakukan pembelian barang-barang kebutuhan sehari-hari di minimarket.

Dengan begitu banyak minimarket yang tersebar di seluruh pelosok kota bahkan sekarang sudah masuk ke desa-desa tentunya akan menimbulkan persaingan diantara pengusaha yang berkecimpung dalam bisnis ini. Di Banyuasin sendiri terdapat sejumlah minimarket yang sudah dikenal oleh masyarakat sebut saja Megamart, Alfamart, Indomaret dan lain-lain.

Super Daily Mart Betung adalah perusahaan yang bergerak di bidang 
retail yang melayani kebutuhan masyarakat akan kebutuhan seharihari. Seiring dengan besarnya pertumbuhan Super Daily Mart Betung ini perhatian terhadap kepuasan atau ketidakpuasan konsumen semakin besar. Persaingan yang semakin ketat khususnya untuk bisnis minimarket. Untuk dapat mempertahankan konsumen yang sudah ada maka perusahaan harus dapat memuaskan konsumennya.

Menurut Kotler (2013:26), konsumen di definisikan sebagai individu atau kelompok yang berusaha memenuhi atu mendapatkan barang atau jasa yang di pengaruhi untuk kehidupan pribadi atau kelompoknya. Kepuasan konsumen sangat ditentukan oleh kualitas produk dan kualitas pelayanan yang menjadi faktor yang utama terhadap keberhasilan suatu perusahaan. Menurut Kotler (2014:83), definisi kualitas pelayanan adalah segala bentuk aktivitas yang dilakukan oleh perusahaan guna memenuhi harapan konsumen. Pelayanan dalam hal ini diartikan sebagai jasa atau service yang disampaikan oleh pemilik jasa yang berupa kemudahan, kecepatan, hubungan, kemampuan dan keramahtamahan yang ditujukan melalui sikap dan sifat dalam memberikan pelayanan untuk kepuasan konsumen. Bentuk definisi kualitas pelayanan ini antara lain dengan melalui penyedian barang yang berkualitas, harga yang kompetitif dan cara mendisplay produk-produk yang menarik. Hal ini merupakan pertahanan yang paling baik untuk menghadapi persaingan ketat yang menyebabkan para retailer harus menempatkan kepuasan konsumen sebagai tujuan utama, sehingga kini menjadi salah satu penentu suksesnya suatu usaha ritel.

Menurut Kotler (2014), kepuasan konsumen itu sendiri dapat di definisikan sebagai individu atau kelompok yang berusaha memenuhi atau mendapatkan barang atau jasa yang dipengaruhi untuk kehidupan pribadi atau kelompoknya. Fenomena ini menguatkan bahwa kepuasan konsumen merupakan asset berharga yang harus dijaga, apabila konsumen mulai tidak puas atas perilaku tersebut maka kemungkinan konsumen akan beralih ke pesaing, sehingga ini akan merugikan perusahaan. Bila kasus ini dibiarkan terus, kemungkinan dalam jangka panjang konsumen Super Daily Mart Betung akan mengalami penurunan. Dampak paling buruk konsumen Super Daily Mart Betung akan berkurang yang berakibat pada keberlangsungan Super Daily Mart Betung ke depannya. Melihat kondisi tersebut, untuk menunjang bisnis minimarket yang berkualitas, pihak Super Daily Mart Betung harus memenuhi kebutuhan para konsumen dalam bentuk pelayanan jasa yang diberikan agar mereka puas.

Kualitas pelayanan memiliki hubungan yang erat dengan kepuasan konsumen. Kualitas memberikan suatu dorongan kepada konsumen untuk menjalin hubungan yang kuat dengan perusahaan untuk memahami dengan sesama harapan konsumen serta kebutuhan mereka. Dengan demikian perusahaan dapat meningkatkan kepuasan konsumen di mana perusahaan memaksimumkan pengalaman konsumen yang menyenangkan dan meminimumkan pengalaman konsumen yang kurang menyenangkan.

\section{B. Rumusan Masalah}

Adapun rumusan masalah yang ingin peneliti kemukakan dalam penelitian ini adalah "apakah ada pengaruh kualitas pelayanan terhadap kepuasan konsumen pada Super Daily Mart Betung?" 
C. Metode Penelitian

Metode penelitian ini menurut Sugiyono (2015:24), metode peneliltian adalah cara ilmiah untuk mendapatkan data dengan tujuan dan kegunaan tertentu. Metode penelitian data yang digunakan dalam penelitian ini adalah metode kuantitatif.

Menurut Sugiyono (2015:35), metode kuantitatif yaitu metode penelitian yang digunakan untuk meneliti pada populasi atau sampel tertentu. Teknik pengumpulan sampel pada umumnya dilakukan secara random, pengumpulan data menggunakan instrumen peneliti. Analisis data bersifat kuantitatif/ statistik dengan tujuan untuk menguji hipotesis yang telah ditetapkan.

\section{Populasi dan Sampel}

1) Populasi

Menurut Sugiyono (2015:148), populasi adalah wilayah generalisasi yang terdiri atas objek / subjek yang mempunyai kuantitas dan karakteristik tertentu yang di tetapkan oleh peneliti untuk di pelajari dan kemudian ditarik kesimpulannya.

Populasi dalam penelitian ini adalah konsumen Super Daily Mart Betung pada bulan Oktober 2017 sebanyak 9.934 konsumen dibagi 4 minggu berarti populasi rata-rata dalam penelitian ini adalah 2.484 konsumen.

\section{2) Sampel}

Menurut Sugiyono (2015:149), sampel adalah sebagian atau wakil populasi yang diteliti. Teknik pengambilan sampel dengan sampel non probalitas yaitu menggunakan metode insidental sampling. Insidental adalah mengambil sampel berdasarkan kebetulan, yaitu siapa saja yang secara kebetulan bertemu dapat digunakan sebagai sampel. Jumlah sampel yang ditetapkan oleh peneliti, mengacu kepada rumus Slovin sebagai berikut :

$$
\begin{aligned}
n & =\frac{N}{1+\left(N . e^{2}\right)}=\frac{2.484}{1+\left(2.484 \cdot\left(0.1^{2}\right)\right.}=\frac{2.484}{2.584} \\
& =96 \text { respon }
\end{aligned}
$$

Keterangan :

$\mathrm{n}=$ Ukuran sampel

$\mathrm{N}=$ Jumlah populasi

$\mathrm{e}=$ Presisi yang ditetapkan $10 \%$

\section{E. Teknik Pengumpulan Data}

Berdasarkan sumber Metode pengumpulan data dalam penelitian ini adalah:

1) Kuesioner (Angket).

Kuisioner adalah metode pengumpulan data yang dilakukan dengan cara memberikan seperangkat pertanyaan atau pernyataan tertulis kepada responden untuk dijawab.

2) Dokumentasi

Dokumentasi adalah pengumpulan data yang dilakukan melalui dokumen - dokumen yang berkaitan dengan masalah yang berkaitan dalam penelitian tersebut.

\section{F. Teknik Analisis Data}

1) Analisis Regresi Linier Sederhana

Menurut Sujarweni (2015:144), regresi linier sederhana adalah untuk meramalkan atau memprediksi variabel terikat $(\mathrm{Y})$ apabila variabel bebas $(\mathrm{X})$ diketahui : regresi sederhana dapat di analisis karena didasari oleh hubungan fungsional atau hubungan sebab akibat (karusal) variabel bebas $(X)$ terhadap variabel terikat $(\mathrm{Y})$.

Persamaan Regresi di rumuskan :

$Y=a+b X+e$

Keterangan:

$Y$ : Nilai yang diprediksikan

$\alpha$ : Konstanta atau $\mathrm{Y}$ bila $\mathrm{X}=0$

$b$ : Koefisien regresi

$x$ : Nilai variabel independen.

e: Term error 


\section{2) Analisis Koefisien Korelasi Sederhana ( $r$ )}

Menurut Sugiyono (2015:128), analisis koefisien korelasi ini dimaksudkan untuk mengetahui pengaruh antara dua variabel yang diteliti, yaitu variabel kualitas pelayana (X) terhadap variabel kepuasan konsumen ( $\mathrm{Y})$. Analisis koefisien korelasi akan dilakukan dengan menggunakan program SPSS versi 22.0.

\section{3) Uji t (secara terpisah)}

Menurut Sujarweni (2015:161), uji t merupakan uji untuk mempengaruhi pengaruh variabel-variabel bebas secara terpisah (parsial) terhadap variabel terikat.

a) Menentukan Ho dan $\mathrm{Ha}$

Ho : tidak ada pengaruh kualitas pelayanan secara terpisah (parsial) terhadap kepuasan konsumen pada Super Daily Mart Betung.

$\mathrm{Ha}$ : Adanya pengaruh kualitas pelayanan secara terpisah (parsial) terhadap kepuasan konsumen pada Super Daily Mart Betung.

b) Menarik kesimpulan.

$\mathrm{Ho}$ : ditolak dan $\mathrm{Ha}$ diterima apabila $t$ hitung $\geq$ tabel artinya ada pengaruh antara kualitas pelayanan dengan kepuasan konsumen pada Super Daily Mart Betung.

$\mathrm{Ho}$ : diterima dan $\mathrm{Ha}$ ditolak apabila thitung $<$ ttabel artinya tidak ada pengaruh antara kualitas pelayanan dengan kepuasan konsumen pada Super Daily Mart Betung.

G. Hasil Penelitian

1) Hasil Uji Coba Instrumen

\section{Variabel}

Penelitian

mnegetahui pengaruh kualitas

pelayanan terhadap kepuasan konsumen pada minimarket Super Daily Mart Betung yang dilakukan dengan cara menggunakan analisis kolerasi, determinasi dan regresi sederhana. Namun sebelum itu terlebih dahulu penelitian melakukan uji coba instrumen penelitian (kuisioner) yang didapat dari kuisioner yang telah disebarkan kepada 96 responden yang merupakan konsumen minimarket Super Daily Mart Betung untuk dimasukkan kedalam rumus validitas dan reabilitas kuisioner tersebut yang berisikan 18 pertanyaan yang terbagi menjadi 10 pertanyaan untuk variabel kualitas pelayanan (X) dan 8 pertanyaan untuk kepuasan konsumen (Y).

TABEL 1

JAWABAN RESPONDEN ATAS VARIABEL KUALITAS PELAYANAN (X)

\begin{tabular}{|c|l|c|c|c|c|c|}
\hline No & Pertanyaan & SS & S & N & TS & STS \\
\hline 1 & Pertanyaan 1 & 0 & 34 & 57 & 5 & 0 \\
& & $(0 \%)$ & $(35,42 \%)$ & $(59,38 \%)$ & $(5,20 \%)$ & $(0 \%)$ \\
\hline 2 & Pertanyaan 2 & 0 & 29 & 65 & 2 & 0 \\
& & $(0 \%)$ & $(30,21 \%)$ & $(67,71 \%)$ & $(2,08 \%)$ & $(0 \%)$ \\
\hline 3 & Pertanyaan 3 & 1 & 35 & 54 & 6 & 0 \\
& & $(1,04 \%)$ & $(36,46 \%)$ & $(56,25 \%)$ & $(6,25 \%)$ & $(0 \%)$ \\
\hline 4 & Pertanyaan 4 & 1 & 31 & 61 & 3 & 0 \\
& & $(1,04 \%)$ & $(32,29 \%)$ & $(63,54 \%)$ & $(3,13 \%)$ & $(0 \%)$ \\
\hline 5 & Pertanyaan 5 & 1 & 27 & 64 & 4 & 0 \\
& & $(1,04 \%)$ & $(28,17 \%)$ & $(66,67 \%)$ & $(4.17 \%)$ & $(0 \%)$ \\
\hline 6 & Pertanyaan 6 & 0 & 27 & 67 & 2 & 0 \\
& & $(0 \%)$ & $(28,17 \%)$ & $(69,79 \%)$ & $(2,08 \%)$ & $(0 \%)$ \\
\hline
\end{tabular}




\begin{tabular}{|c|l|c|c|c|c|c|}
\hline 7 & Pertanyaan 7 & 0 & 51 & 44 & 1 & 0 \\
& & $(0 \%)$ & $(53,16 \%)$ & $(45,83 \%)$ & $(1,04 \%)$ & $(0 \%)$ \\
\hline 8 & Pertanyaan 8 & 1 & 42 & 51 & 2 & 0 \\
& & $(1,04 \%)$ & $(43,75 \%)$ & $(53,16 \%)$ & $(2,08 \%)$ & $(0 \%)$ \\
\hline 9 & Pertanyaan 9 & 0 & 43 & 51 & 2 & 0 \\
& & $(0 \%)$ & $(44,79 \%)$ & $(53,16 \%)$ & $(2,08 \%)$ & $(0 \%)$ \\
\hline 10 & Pertanyaan 10 & 0 & 43 & 53 & 0 & 0 \\
& & $(0 \%)$ & $(44,79 \%)$ & $(55,21 \%)$ & $(0 \%)$ & $(0 \%)$ \\
\hline
\end{tabular}

Sumber data: pengolahan data primer 2017

Dari tabel di atas dapat dilihat tanggapan responden terhadap variabel kualitas pelayanan (X) bervariasi dan mayoritas menyatakan netral. Meskipun terdapat indikator yang setujunya cukup tinggi, yaitu pada pertanyaan 7,8,9 dan 10 .

TABEL 2

JAWABAN RESPONDEN ATAS VARIABEL KEPUASAN KONSUMEN $(Y)$

\begin{tabular}{|c|l|c|c|c|c|c|}
\hline No & Pertanyaan & SS & S & N & TS & STS \\
\hline 1 & Pertanyaan 1 & 0 & 45 & 51 & 0 & 0 \\
& & $(0 \%)$ & $(46,88 \%)$ & $(53,13 \%)$ & $(0 \%)$ & $(0 \%)$ \\
\hline 2 & Pertanyaan 2 & 1 & 57 & 38 & 0 & 0 \\
& & $(1,04 \%)$ & $(59,76 \%)$ & $(39,58 \%)$ & $(0 \%)$ & $(0 \%)$ \\
\hline 3 & Pertanyaan 3 & 1 & 56 & 38 & 1 & 0 \\
& & $(1,04 \%)$ & $(58,33 \%)$ & $(39,58 \%)$ & $(1,04 \%)$ & $(0 \%)$ \\
\hline 4 & Pertanyaan 4 & 1 & 51 & 44 & 0 & 0 \\
& & $(1,04 \%)$ & $(53,16 \%)$ & $(45,83 \%)$ & $(0 \%)$ & $(0 \%)$ \\
\hline 5 & Pertanyaan 5 & 1 & 60 & 34 & 1 & 0 \\
& & $(1,04 \%)$ & $(62,5 \%)$ & $(35,42 \%)$ & $(1,04 \%)$ & $(0 \%)$ \\
\hline 6 & Pertanyaan 6 & 2 & 51 & 41 & 2 & 0 \\
& & $(2,08 \%)$ & $(53,13 \%)$ & $(42,71 \%)$ & $(2,08 \%)$ & $(0 \%)$ \\
\hline 7 & Pertanyaan 7 & 2 & 45 & 49 & 0 & 0 \\
& & $(2,08 \%)$ & $(46,88 \%)$ & $(51,04 \%)$ & $(0 \%)$ & $(0 \%)$ \\
\hline 8 & Pertanyaan 8 & 0 & 34 & 62 & 0 & 0 \\
& & $(0 \%)$ & $(35,42 \%)$ & $(64,58 \%)$ & $(0 \%)$ & $(0 \%)$ \\
\hline
\end{tabular}

Sumber data: pengolahan data primer 2017

Dari tabel di atas dapat dilihat tanggapan responden terhadap variabel kepuasan konsumen (Y) bervariasi dan mayoritas menyatakan setuju. Meskipun terdapat indikator yang netralnya cukup tinggi, yaitu pada pertanyaan 1,7 dan 8 .

\section{2) Hasil Uji Validitas}

Uji validitas digunakan untuk mengukur sah atau valid tidaknya suatu kuisioner. Kuisioner dikatakan valid jika pertanyaan sesuatu yang akan dan pada kuisioner mampu untuk mengungkapkan sesuatu yang akan diukur oleh kuisioner tersebut. Untuk menghitung uji validitas, bandingkan nilai correlated item-total correlations ( $\mathrm{r}_{\text {hitung }}$ ) dengan hasil perhitungan ( $\left.\mathrm{r}_{\text {tabel }}\right)$. Seperti pertanyaan berikut:

Apabila ( $r$ hitung $>r$ tabel ) maka pertanyaan atau indikator tersebut valid

Apabila ( $r$ hitung $<r$ tabel) maka pertanyaan atau indikator tersebut tidak valid.

Proses validitas dilakukan terhadap butir-butir pertanyaan instrumen, hal ini dilakukan dengan membandingkan hasil perhitungan $r$ Product momemt dengan nilai $r$ tabel pada $n-2,96-2=94$. Sedangkan butir instrumen dapat dinyatakan valid 
dan dapat digunakan pada penelitian jika skor $r$ hitung $>r$ tabel $(0,200)$, sebaliknya jika $r$ hitung $<r$ tabel $(0,200)$ maka butir instrumen dinyatakan tidak valid dan tidak digunakan. Hasil perhitungan uji validitas butir instrumen pada masing-masing variabel penelitian sebagai berikut:

1. Hasil uji validitas instrumen kualitas pelayanan $(X)$

TABEL 3

HASIL UJI VALIDITAS KUALITAS PELAYANAN (X)

\begin{tabular}{|c|c|c|c|c|}
\hline No & Pertanyaan & $\mathbf{r}$ hitung & $\mathbf{r}$ tabel & Keterangan \\
\hline 1 & Item_1 & 0,374 & 0,200 & Valid \\
\hline 2 & Item_2 & 0,542 & 0,200 & Valid \\
\hline 3 & Item_3 & 0,456 & 0,200 & Valid \\
\hline 4 & Item_4 & 0,517 & 0,200 & Valid \\
\hline 5 & Item_5 & 0,470 & 0,200 & Valid \\
\hline 6 & Item_6 & 0,431 & 0,200 & Valid \\
\hline 7 & Item_7 & 0,256 & 0,200 & Valid \\
\hline 8 & Item_8 & 0,268 & 0,200 & Valid \\
\hline 9 & Item_9 & 0,328 & 0,200 & Valid \\
\hline 10 & Item_10 & 0,432 & 0,200 & Valid \\
\hline
\end{tabular}

Sumber : Pengolahan data primer 2017

Dari data perhitungan SPSS 22 for windows diperoleh hasil bahwa validitas kuisioner untuk semua pertanyaan tentang variabel kualitas pelayanan $(X$ adalah valid, karena $r$ hitung $>r$ tabel $(0,200$ pada level signifikan $5 \%$ dengan $\mathrm{df}=96)$.

2. Hasil uji validitas instrumen variabel kepuasan konsumen $(\mathrm{Y})$

TABEL 4

HASIL UJI VALIDITAS KEPUASAN KONSUMEN (Y)

\begin{tabular}{|c|c|c|c|c|}
\hline No & Pertanyaan & $\mathbf{r}$ hitung & $\mathbf{r}$ tabel & Keterangan \\
\hline 1 & Item_1 & 0,317 & 0,200 & Valid \\
\hline 2 & Item_2 & 0,414 & 0,200 & Valid \\
\hline 3 & Item_3 & 0,515 & 0,200 & Valid \\
\hline 4 & Item_4 & 0,621 & 0,200 & Valid \\
\hline 5 & Item_5 & 0,560 & 0,200 & Valid \\
\hline 6 & Item_6 & 0,617 & 0,200 & Valid \\
\hline 7 & Item_7 & 0,484 & 0,200 & Valid \\
\hline 8 & Item_8 & 0,456 & 0,200 & Valid \\
\hline \multicolumn{5}{|l}{} \\
\multicolumn{5}{l}{ Sumber: Pengolahan data primer 2017 } \\
\end{tabular}

Dari data perhitungan SPSS 22 for windows diperoleh hasil bahwa validitas kuisioner untuk semua pertanyaan tentang kepuasan konsumen $(\mathrm{Y})$ adalah valid, karena $r$ hitung $>r$ tabel $(0,200$ pada level signifikan $5 \%$ dengan $\mathrm{df}=96$ ).

\section{3) Hasil Uji Reliabilitas}

Menurut Arikunto (2013:211) Uji reliabilitas adalah alat untuk mengukur suatu kuisioner yang merupakan indikator dari variabel. Butir pertanyaan dikatakan reliabel atau handal apabila jawaban seseorang terhadap pertanyaan adalah konsisten. Suatu konstruk atau variabel dikatakan reliabel jika memberikan nilai 
Cronbach's Alpha > 0,60. Berikut hasil uji reliabilitas masing-masing variabel.

a) Hasil reliabilitas instrumen Uji reliabilitas digunakan untuk mengukur suatu kuisioner yang merupakan indikator dari variabel. Reliabilitas diukur dengan uji statistik Cronbach's Alpha (a). Suatu variabel dikatakan reliabel jika memberikan nilai Cronbach's Alpha > 0,200. Hasil uji reliabilitas variabel kualitas pelayanan (X) dengan menggunakan SPSS 22 for windows yaitu dengan hasil seperti tabel dibawah ini :

\section{TABEL 5}

Hasil Uji Reliabilitas

Instrumen Variabel Kualitas Pelayanan (X)

Reliability Statistics

\begin{tabular}{|r|r|}
\hline Cronbach's Alpha & N of Items \\
\hline, 744 & 10 \\
\hline
\end{tabular}

Hasil uji reliabilitas didapat Cronbach's Alpha sebesar 0,744 > 0,200 . Karena nilai diatas 0,200 maka dapat disimpulkan bahwa instrumen variabel kualitas pelayanan ( $\mathrm{X}$ ) dalam penelitian ini reliabel dan dapat dijadikan alat ukur dianalisis selanjutnya.

b) Hasil reliabilitas instrumen variabel kepuasan konsumen $(Y)$
Hasil uji reliablitas variabel kepuasan konsumen (Y) dengan menggunakan SPPS 22 for windows yaitu dengan hasil tabel dibawah Ini:

TABEL 6

Hasil Uji Reliabilitas

Instrumen Variabel Kepuasan Konsumen ( $\mathrm{Y}$ ) Reliability Statistics

\begin{tabular}{|r|r|}
\hline Cronbach's Alpha & N of Items \\
\hline, 792 & 8 \\
\hline \multicolumn{2}{|c|}{ Sumber : Output SPSS for windows 2017}
\end{tabular}

Hasil uji reliabilitas didapat nilai Cronbach's Alpha sebesar 0,792 > 0,200 . Karena nilai diatas 0,200 maka dapat disimpulkan bahwa instrumen variabel kepuasan konsumen dalam penelitian ini reliabel dan dapat dijadikan alat ukur analisis selanjutnya.

\section{4) Hasil Uji Normalitas}

Menurut Sunyoto (2014:84), uji normalitas akan menguji data variabel bebas $(\mathrm{X})$ dan data variabel terikat $(\mathrm{Y})$ pada persamaan regresi yang dihasilkan apakah berdistribusi normal atau berdistribusi tidak normal. Uji normalitas dapat dilakukan dengan analisis grafik histrogram dan normal probability plots yang dapat di deteksi dengan melihat penyebaran data (titik) pada sumbu diagonal dari grafik. Uji normalitas pada penelitian ini menggunakan uji normalitas probability plot. 


\section{Gambar 1 \\ Pengujian Normalitas}

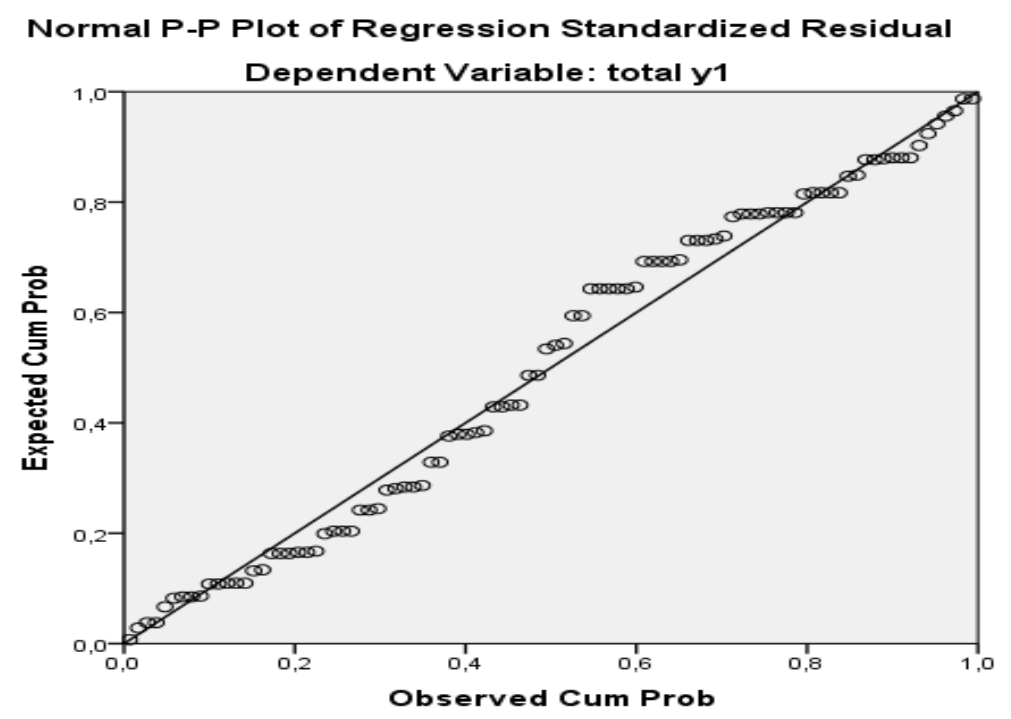

Sumber: data diolah, 2017

\section{5) Teknik Analisis Data}

a) Analisis Regresi Linier sederhana

Analisis regresi linier sederhana digunakan dalam penelitian ini dengan tujuan membuktikan hipotesis mengenai pengaruh variabel kualitas pelayanan $(\mathrm{X})$ terhadap variabel kepuasan konsumen $(\mathrm{Y})$.

TABEL 7

HASIL ANALISIS REGRESI LINIER SEDERHANA

Coefficients $^{\mathrm{a}}$

\begin{tabular}{|c|c|c|c|c|c|}
\hline \multirow[b]{2}{*}{ Model } & \multicolumn{2}{|c|}{$\begin{array}{c}\text { Unstandardized } \\
\text { Coefficients }\end{array}$} & \multirow{2}{*}{$\begin{array}{c}\text { Standardized } \\
\text { Coefficients } \\
\text { Beta }\end{array}$} & \multirow[b]{2}{*}{ t } & \multirow[b]{2}{*}{ Siq. } \\
\hline & B & $\begin{array}{l}\text { Std. } \\
\text { Error }\end{array}$ & & & \\
\hline 1 (Constant) & 16,814 & 2,926 & & 5,747 &, 000 \\
\hline $\begin{array}{l}\text { Kualitas } \\
\text { Pelayanan }\end{array}$ & ,342 & ,087 & ,376 & 3,938 & ,000 \\
\hline
\end{tabular}

a. Dependent Variable: Kepuasan konsumen_Y

Sumber: hasil output SPSS 22For Windows, 2017

Berdasarkan tabel tersebut, diperoleh nilai koefisen regresi untuk kualitas pelayanan (b) sebesar 0,342 dan koefesien konstantanya sebesar 16,814 berdasarkan nilai tersebut diperoleh persamaan regresi sebagai berikut :

$$
\begin{aligned}
& Y^{\prime}=\boldsymbol{a}+\boldsymbol{b X} \\
& Y=16,814+0,342
\end{aligned}
$$

Model di atas dapat diartikan bahwa :

$$
\text { 1. } a=16,814
$$

Nilai konstanta ini menunjukan bahwa apabila tidak ada variabel independen (kualitas pelayanan) $\mathrm{X}=0$, Maka kualitas pelayanan adalah 16,814

2. $b=0,342$

Koefisien regresi b ini menunjukan bahwa variabel kualitas pelayanan dingkatkan sebesar satu satuan, maka kepuasan konsumen akan meningkat 0,342 satuan. 
Sebaliknya jika variabel kualitas pelayanan menurun satu satuan, maka kepuasan konsumen akan menurun sebesar 0,342.

b) Analisis Koefisien Determinasi $\left(r^{2}\right)$
Koefisien korelasi ini digunakan untuk mengukur keeratan suatu hubungan variabel kualitas pelayanan (X) terhadap variabel kepuasan konsumen $(\mathrm{Y})$.

TABEL 8

HASIL UJI DETERMINASI $\left(\mathbf{r}^{2}\right)$

Model Summary

\begin{tabular}{|l|c|r|r|r|}
\hline Model & $\mathrm{R}$ & $\mathrm{R}$ Square & $\begin{array}{c}\text { Adjusted R } \\
\text { Square }\end{array}$ & $\begin{array}{c}\text { Std. Error of the } \\
\text { Estimate }\end{array}$ \\
\hline 1 &, $376^{\mathrm{a}}$ &, 142 & \multicolumn{1}{c|}{, 133} & 2,506 \\
\hline
\end{tabular}

a. Predictors: (Constant), Kualitas Pelayanan

b. Dependent Variabie: Kepuasan Konsumen

Sumber: hasil output SPSS 22 For Windows, 2017

Menurut Sujarweni (2015:128), analisis koefisien korelasi ini dimaksudkan untuk mengetahui pengaruh antara dua variabel yang diteliti, yaitu variabel kualitas pelayanan (X) terhadap variabel kepuasan konsumen (Y). Analisis koefisien korelasi akan dilakukan dengan menggunakan program SPSS versi 22.0. Untuk mengidentifikasi tinggi rendahnya koefisien korelasi digunakan kriteria seperti tabel dibawah ini.

TABEL 9

INTERPRETASI KOEFISIEN KORELASI NILAI (r)

\begin{tabular}{|c|c|}
\hline Interpretasi Koefisien & Tingkat Hubungan \\
\hline $0,80-1,000$ & Sangat Kuat \\
$0,60-0,799$ & Kuat \\
$0,40-0,599$ & Cukup \\
$0,20-0,399$ & Rendah \\
$0,00-0,199$ & Sangat Rendah \\
\hline
\end{tabular}

Koefisien kolerasi ( $r$ ) adalah 0,376 maka dapat disimpulkan bahwa terjadi hubungan yang rendah antara kualitas pelayanan dan kepuasan konsumen pada kisaran 0,20 - 0,399. Sedangkan pada interpretasi koefisien determinasi $\left(r^{2}\right)$ sebesar $0,142 \quad(14,2 \%)$ dapat disimpulkan bahwa kualitas pelayanan berpengaruh terhadap kepuasan konsumen sebesar 0,142 atau $14,2 \%$ sedangkan sisanya $85,8 \%$ dipengaruhi oleh variabel-variabel lainnya yang tidak diteliti dalam penelitian ini seperti harga produk, kualitas produk, keanekaragaman produk dan lain-lain.

\section{6) Uji Hipotesis Penelitian (Uji t)}

Uji t digunakan untuk mengetahui pengaruh variabel kualitas pelayanan (X) terhadap variabel kepuasan konsumen $(\mathrm{Y})$ dimana $\mathrm{dk}=\mathrm{n}$-jumlah variabel bebas dan $\alpha=0,05$ tabel 1,661. Berikut hasil pengujian yang diperoleh: 
TABEL 10

HASIL UJI $t$

Coefficients $^{a}$

\begin{tabular}{|ll|r|r|r|r|r|}
\hline \multirow{2}{*}{ Model } & \multicolumn{2}{|c|}{$\begin{array}{c}\text { Unstandardized } \\
\text { Coefficients }\end{array}$} & $\begin{array}{c}\text { Standardized } \\
\text { Coefficients }\end{array}$ & & \\
\cline { 2 - 7 } & \multicolumn{2}{|c|}{$\mathrm{B}$} & Std. Error & Beta & \multicolumn{1}{c|}{ Sig. } \\
\hline (Constant) & 16,814 & 2,926 & & 5,747 &, 000 \\
& Kualitas Pelayanan &, 342 &, 087 &, 376 & 3,938 &, 000 \\
\hline
\end{tabular}

a. Dependent Variable: Kepuasan konsumen

Sumber output SPSS 22 For Windows, 2017

Hasil uji t dari perhitungan regresi linier sederhana antara kualitas pelayanan dan kepuasan konsumen diperoleh thitung $=3,938$ dengan tingkat signifikasi 0,000 . Dengan menggunakan batas 0,05 didapat tabel 1,661 yang berarti thitung > tabel, maka hipotesis Ho ditolak dan Ha diterima. Dengan demikian dapat disimpulkan bahwa ada pengaruh antara kualitas pelayanan terhadap kepuasan konsumen. Hal ini sesuai dengan kriteria pengujian dimana:

Ho diterima, Ha ditolak jika p-value (sig) $>0,05$, bahwa tidak ada pengaruh signifikan antara kualitas pelayanan dan kepuasan konsumen.

Ho ditolak, Ha diterima jika $\mathrm{p}$-value (sig) $<0,05$, artinya ada pengaruh signifikan antara kualitas pelayanan dan kepuasan konsumen.

\section{H. Pembahasan}

1. Regresi Linier Sederhana

Berdasarkan hasil perhitungan diperoleh persamaan regresi linier sederhana adalah $\mathrm{Y}=16,814+$ 0,342X, berdasarkan output coefficients diketahui nilai koefisien regresi kualitas pelayanan sebesar 0,342 dengan signifikan 0,000 atau $0 \%$ $<5 \%$ berarti signifikan untuk memprediksi nilai kepuasan konsumen. Dimana jika nilai kualitas pelayanan $(X)$ naik sebesar satu satuan maka prediksi nilai kepuasan konsumen $(\mathrm{Y})$ naik sebesar 0,342 dan sebaliknya jika berkurang satu satuan nilai kualitas pelayanan $(X)$ maka prediksi nilai kepuasan konsumen $(\mathrm{Y})$ berkurang sebesar 0,342.

\section{Koefisien Determinasi $\left(r^{2}\right)$}

Penelitian ini sejalan dengan penelitian terdahulu yang dilakukan oleh Evi Nur Apriyani (2012) dan Ardiawan Wendi Happy (2009) yang menunjukan ada pengaruh antara kualitas pelayanan terhadap kepuasan pelanggan. Dimana hasil penelitian dapat disimpulkan dari interpretasi determinasi $\left(r^{2}\right)$ sebesar $0,142(14,2 \%)$, hal ini menunjukan bahwa kualitas pelayanan berpengaruh terhadap kepuasan konsumen sebesar 0,142 atau $14,2 \%$ sedangkan sisanya $85,8 \%$ dipengaruhi oleh variabel-variabel lainnya yang tidak diteliti dalam penelitian ini seperti harga produk, kualitas produk, keanekaragaman produk dan lain-lain.

\section{Uji Hipotesis}

Selanjutnya hasil pengujian hipotesis diperoleh nilai $p$-value (sig) $0,000<0,05$. Jadi dari hasil penelitian sebelumnya dapat disimpulkan bahwa variabel kualitas pelayanan (X) berpengaruh terhadap variabel kepuasan konsumen $(Y)$. 
I. Kesimpulan dan Saran

1) Kesimpulan

a) Berdasarkan perhitungan regresi linier sederhana nilai koefisien regresi untuk kualitas pelayanan 0,342 dan koefisien konstanta sebesar 16,814 berdasarkan nilai tersebut diperoleh persamaan regresi linier sederhana adalah: $Y$ $=16,814+0,342 X+2,926 e$, dan output coefficients diketahui nilai koefisien regresi kualitas pelayanan 0,342 dengan signifikansi $0,000 \%$ atau $0 \%<5 \%$ berarti signifikan untuk memprediksi nilai kepuasan konsumen. Dimana jika variabel $X$ (kualitas pelayanan) naik sebesar satu satuan maka variabel $Y$ (kepuasan konsumen) naik sebesar 0,342 dan sebaliknya jika variabel $X$ (kualitas pelayanan) berkurang satu satuan maka variabel $\mathrm{Y}$ (kepuasan konsumen) berkurang sebesar 0,342 .

b) Berdasarkan hasil pengujian dengan menggunakan program SPSS Versi 22.0 maka diperoleh nilai $\mathrm{Uji} \mathrm{t}=3,938$ atau nilai $\mathrm{p}$ value (sig) variabel kualitas pelayanan $(X)$ sebesar 0,000 karena nilai $p$-value $0,000<0,05$ maka kriteria pengujian hipotesis Ho ditolak, $\mathrm{Ha}$ diterima, dari analisis tersebut dapat disimpulkan bahwa kualitas pelayanan berpengaruh signifikan terhadap kepuasan konsumen pada Super Daily Mart Betung.

\section{2) Saran}

Berdasarkan kesimpulan diatas, maka peneliti memberikan saran sebagai berikut:

a) Hendaknya Super Daily Mart Betung harus memperhatikan dari segi kualitas pelayanan dalam customer servis, seperti pertama, aktif dalam $3 S$ (senyum, salam, sapa). Kedua, memperhatikan dan mengarahkan konsumen/pelanggan tentang apa yang di butuhkannya. Ketiga, mendengar keluhan konsumen dan yang terakhir berikan kesan yang baik pada konsumen dengan kata "terima kasih atas kunjungan, kami nantikan kunjungan anda kembali".

b) Perlunya memperhatikan display produk agar produk yang dipajang mempunyai daya tarik sehingga memudahkan konsumen mencari produk yang diinginkan.

c) Harga yang tertera pada papan produk sesuai dengan apa yg ada dikasir disaat kita melakukan transaksi pembayaran.

d) Untuk meningkatkan kualitas pelayanan diperlukan kehandalan wiraniaganya tidak hanya penampilan tapi cakap dalam berbicara, tahu tentang produk, cara menghadapi konsumen, cara mengatasi komplain dari konsumen dan harus mengetahui karakter konsumen. Semua itu perlu diadakan pelatihan khusus atau training.

\section{DAFTAR PUSTAKA}

Apriyani, Evi Nur. 2012. Pengaruh kualitas pelayanan terhadap kepuasan pelanggan SPBU Coco 2130204 Pemasaran Fuel Retail Marketing Region 2 PT Pertamina (Persero) Subagsel.(diakses 14 juni 2016)

Arikunto, Suharsimi. 2013. Prosedur Penelitian Suatu Pendekatan Praktik, Ed. Revisi. Jakarta: PT. Rineka Cipta. 
Ardiawan, Wendi Happy. 2009. Pengaruh kualitas pelayanan terhadap kepuasan pelanggan (studi kasus pada luwes loji wetan solo). Universitas Sebelas Maret. Surakarta https://digilib.uns.ac.id/.(diakses 16 mei 2016)

Danang Sunyoto. 2014. Praktik Riset Perilaku Konsumen (Teori, kuesioner, alat dan analisis data) Yogyakarta.

Kotler dan Keller. 2014. Manajemen Pemasaran. Jakarta Barat: PT Indeks Permata Puri Media.
Kotler dan Amstrong. 2008. Prinsip prinsip Manajemen Edisi Kedua. Jakarta : Salemba Empat.

Sugiyono. 2015. Metodologi Penelitian Manajemen . Jakarta : Salemba Empat

Sugiyono. 2015. Metode Penelitian Bisnis. Bandung: Alfabeta.

Sujarweni,Wiratna V, 2015. SPSS Untuk Penelitian. Cetakan Pertama. Yogyakarta : Pustaka Baru Press. 